УДК 159.923.2

\author{
Геннадій Грибенюк, \\ доктор психологічних наук, професор, \\ Черкаський інститут пожежної безпеки \\ імені Героїв Чорнобиля НУЦЗ України, м. Черкаси \\ ORCID ID 0000-0002-5053-8744 \\ DOI: $10.33099 / 2617-1775 / 2019-02 / 52-61$
}

\title{
РОЗВИТОК ХАРАКТЕРИСТИК САМОАКТИТВНОСТІ КУРСАНТА
}

Резюме. Стаття розкриває особливості проведеного аналізу дій викладача по розвитку самоактивності курсантів на занятті. Представлені результати роботи дозволяють визначити, з огляду на специфіку професійної діяльності ДСНС Украӥни, необхідні обтрунтованих критерїв і типів самосуб'єктної активності курсантів. Подальші дослідження необхідні для вивчення психологічних умов ефективної підготовки курсантів у закладах вищої освіти.

Ключові слова: самоактивність; курсант; самосуб'єктна активність; саморегулячія; самосуб'єктна дія.

Постановка проблеми. Професорсько-викладацький склад у навчальновиховному процесі закладів вищої освіти, вирішує питання про те, у який спосіб краще управляти розвитком курсанта i, передусім, робити 3 нього ефективного суб'єкта власної навчальної діяльності та саморозвитку. На рівні окремого заняття викладач вирішує розвивальне завдання діагностики, корекції та розвитку спроможності курсанта до самосуб'єктних впливів і контролю ознак його психологічної готовності до цього. Робота не ведеться самотужки, іiі суб'єктами є професорсько-викладацький, начальницький склад, психологи. Вона спрямована на те, щоб відшукати можливість технологізувати процес індивідуального розвитку за рахунок необхідних поняттєвих засобів,, підібрати найбільш прийнятні курсанту дидактичні засоби розвитку самоактивності. Виконується водночас на різних рівнях і напрямках необхідної підготовки майбутніх професіоналів.

Аналіз останніх досягнень і публікацій. Аналіз результатів досліджень [1], [2], [3], [4], [5] дозволяє зробити висновок про те, що за умовами виникнення й перебігу екстремальних ситуації лежить протидія, особистості екстремальному, подолання нею певних перешкод, деструктивних впливів i небезпек. Увага науковців зосереджена на функціональних проявах фахівця, особливостях екстремальних викликів, проте, утворення самосвідомості, засоби i технологія процесу підготовки як суб'єкта розвитку власної відповідальності та саморегуляції майже не розкриті. Це повною мірою стосується підготовки курсантів до дій за призначенням у сфері цивільного захисту, які готуються на первинні посади керівників тактичних підрозділів, у пожежно-рятувальних підрозділах.

Мета статті. Мета статті - розкрити необхідні умови активного включення курсанта у процес саморозвитку, який ставить до нього вимоги як до активного суб'єкта власних перетворень. Необхідно розкрити типи 
самосуб'єктних впливів курсантів у ситуаціях навчально-професійної діяльності та проаналізувати їх взаємозв'язок із параметрами професійної діяльності та параметрами задуму на проведення заняття викладачем ВЗО.

Виклад основного матеріалу. Зрозумілою $є$ значущість питання розвитку саморегуляції та самосуб'єктних впливів у курсанта під час його професійного становлення впродовж років навчання у В3О. Ще більшої гостроти набуває необхідність дослідження проблеми активізації внутрішніх резервів курсанта на рівні окремого навчального заняття.

Викладачем ВЗО робота ведеться на двох рівнях - розуміння явища самоактивності курсанта та управління процесом на занятті. На кожному рівні такої, по суті, психологічної роботи, виділяються окремі завдання, які вирізняються суб'єктивними і предметно-практичними цілями та ознаками. У викладача $\epsilon$ необхідність використати належний предметний зміст 3 метою психологічної підготовки. методологічні знання, методичні засоби, психологопедагогічну компетентність і культуру.

На рівні розуміння, розв'язуються завдання, які є дослідницькими за своїм спрямуванням. Для їх проведення необхідна певна теоретична підготовленість викладача, зокрема, знання поняттєвого апарату психології та формулювання, «називання» їх у меті на проведення заняття До таких завдань відноситься:

Фіксація існування явища самосуб'єктного впливу. Змістове наповнення таких мисленнєвих дій виклалача полягає в тому, щоб побачити явище, помітити його, вирізнити у психологічно нерозчленованому повсякденному житті курсанта та у його навчально-професійній діяльності. Якщо явище мало прояви як очевидна проблема, наприклад, не підготовленість курсанта до заняття без поважних причин, то зміст мисленнєвих дій викладача полягає в тому, щоб прийняти дану проблему як пізнавальну до розв'язання та визначити які саме суб'єктні, психологічні причини до неї призвели. Фіксація відбувається подумки як завдання управління рівнем психологічної готовності курсанта до самоактивності, 3 пошуком організаційних, психолого-педагогічних, етичних причин, які призвели до таких наслідків. Фіксацію можна формалізувати записом у журналах індивідуально-виховної роботи, щоденниках наставників, звітах про стан дисципліни у взводах тощо.

Опис явища. Зміст цього етапу пізнавальних дій викладача полягає у тому, щоб дати характеристику явища самоактивності курсанта та його ознак у конкретній педагогічно важливій ситуації, можливо, розгорнуту. Опис відбувається як мовою буденного спілкування «про себе», так і «на зовні», мовою зрозумілою викладачу не-психологу, а також, за допомогою категорій психології, яка виділяє тонкі деталі, особливості вже відомих у психології закономірностей. Зробити опис, - означає перерахувати, поставити у рядок, «через кому» елементи, ознаки вияву самоактивності курсанта.

Дослідження. Це дії викладача, які відносять вже відомі, виявлені курсантом у ситуації ознаки самоактивності, до певних відомих у психології реєстрів ознак, така собі їх класифікація, типологізація. Можуть бути дії узагальнення одержаної психологічної інформації. Це, - мисленнєві дії 
викладача із діапазону методів емпіричного аналізу. Крім зазначених дескрипторів (реєстрації, узагальнення), можливими $є$ спостереження за явищем самоактивності курсанта, вимірювання, експеримент як активна дія.

Пояснення. Інтерпретація наявних даних, побудова власних пояснювальних моделей самоактивності, використання наявних концептуальних знань для пошуку відповідей на питання: «Чому це було?», Що дозволяє пояснити механізми явища самосуб'єктного впливу - його структуру, чинники виникнення і динаміки, залежність між різними параметрамихарактеристиками, або визначити показники і критерії оптимального чи нормативного стану індивідуальних характеристик. Пояснення відноситься до індикаторів перебігу у викладача форм і методів теоретичного пізнання, наявності у його мисленні: фактів, гіпотез, моделей, віднесення наявних даних щодо вияву самоактивності у курсанта до закономірностей, аналізу та синтезу, індукції та дедукції, системності.

Прогнозування. Передбачення, - побудова динамічних моделей перспективного стану готовності курсанта до самосуб'єктного впливу за тих або інших умов управління його саморозвитком.

Рекомендації щодо саморозвитку. Система обгрунтованих пропозицій у зв'язку з проблемою, яка розв'язується - для курсанта, керівників курсантських підрозділів, начальницького складу, фахівців структур по роботі з особовим складом, медиків, - тих, хто має відношення до організаційної структури. Рекомендації можуть носити індивідуальний, або організаційно-управлінський характер, мати різні форми: спілкування, планування корегувальних i формувальних програм, консультування, форм індивідуально-виховній роботі 3 курсантом.

На рівні управління розвитком самоактивності курсанта, робота викладача передбачає практичний вплив на параметри саморозвитку. Виходячи з основних характеристик явища самоактивності курсанта та його інтерпретації викладачем є підстави використати отримані результати аналітико-оціночної роботи у такий спосіб:

1. Корегування саморозвитку. Це, - система дій організаційноуправлінського, психолого-педагогічного, психотерапевтичного плану, які проводяться викладачем, начальницьким складом, психологом, курсантами, по відношенню до відхилень у траєкторії поведінки окремого курсанта в колективі. Поняття «відхилення» та «норма» передбачає знання та обгрунтоване підтвердження необхідності функціонування відповідної норми.

2. Цілеспрямоване формування самоактивності курсанта. Воно має частковий збіг з корегуванням, водночас, і специфічні особливості. Відхилення від бажаного розуміється як певний дефіцит у курсанта необхідних компетентностей відповідно до стандарту. Це дескриптори Національної рамки кваліфікацій: знання, вміння, спроможність до комунікації, автономність та відповідальність [6], а також рівень їх практичної реалізації параметрах дій курсанта. 
Формами роботи може бути організація заходів психологічної підготовки до окремих ситуацій майбутньої професійної діяльності, тренінги, форми спілкування.

3. Сприяння саморозвитку курсанта передбачає його внутрішній розвиток до рівня самостійного аналізу і подолання проблем, які виникають. Роль викладача полягає, передусім, у вмінні досягати позитивних зрушень в автономності дій курсанта, ефективній його діяльності без зовнішніх спонук, в умовах, коли немає безпосереднього впливу зовні, а курсант працює з такими ж параметрами якості, немов би керівний вплив $\epsilon$.

Отже, вищезазначена цільова перспектива мисленнєвих дій викладача $є$ частково розкритою технологією забезпечення розвитку самоактивності курсанта у навчально-професійній діяльності, яка може бути наповнена відповідними поняттєвими $\mathrm{i}$ дидактичними засобами його роботи та «вмонтована» у повну психолого-педагогічну технологію.

Проведене професіографічне вивчення показало, що специфіка професійної діяльності висуває значні вимоги до параметрів саморегулятивних впливів курсантів, зокрема, їх напруженості, величини, оптимального рівня, тривалості в часі, змістових характеристиках саморегулятивних дій. Зумовлена низкою чинників різної природи: середовищних, діяльнісних, особистісних, напруженість саморегулятивних впливів і проявляється в ефективності дій, рівні особистої успішності, адаптованості та адекватності дій курсанта щодо розвитку ситуації.

Значна частина психологів, які вивчають професійну діяльність в екстремальних умовах солідарна у тому, що в результаті саморегулятивних впливів у психіці фахівця відбуваються зміни. Ці зміни розглядаються на різних рівнях, а звідси, існують різні підходи до їх дослідження. Функціональний підхід, відповідно до якого саморегулятивна активність має бути спрямована на розвиток м'язово-рухових та психічних функцій: відчуття, сприймання, наочнодієвого мислення, уваги, вольових якостей тощо. Особистісний підхід стверджує, що саморегулятивні впливи мають бути зосереджені на створення самоактивності загалом, оскільки постійні зміни відбуваються не лише в окремих органах, які беруть участь у виконанні певного руху, а, передусім в особистості, організмі в цілому. Тільки на основі всієї системи змін можливо виявити особливості стійких та динамічних характеристик саморегулятивних впливів у процесі становлення самоактивності курсанта [7, 8, 9].

Саморегулятивні впливи - це свідомий процес відтворення внутрішньої моделі діяльності і регуляції поведінки у напружених ситуаціях на основі особистого досвіду та власних уявлень про розвиток ситуації.

Змістом процесу самоактивності необхідно вважати систему компетентностей, засобів діяльності суб'єкта, що визначають спроможність управляти своєю поведінкою, станами та діяльністю під час виконання поставленого завдання, а також сформованість механізмів саморегуляції.

У науковій літературі немає єдності у виокремленні конкретної системи якостей, які характеризують специфіку саморегулятивних впливів у ситуаціях 
виконання навчально-професійного завдання. Результатом саморегулятивних впливів пропонують вважати добре розвинені розумові, емоційні, вольові процеси та навички, без вказівок на їх конкретний зміст, що ускладнює їх виявлення у конкретного фахівця. Виокремлюють моральну регуляцію i професійно важливі якості та вважають їх сформованість результатом самоактивності [8].

На основі проведеного емпіричного та теоретичного аналізу самоактивності фахівців в екстремальних умовах, 3 огляду на результати професіографічного вивчення, ми провели типологізацію саморегулятивної активності за їі рівнями. Розроблені критерії та показники, які у своїй сукупності складають методичний інструментарій для практичного визначення саморегулятивної активності курсантів.

Критерії та показники самоактивності курсантів у навчально-професійній діяльності:

- прагнення до розв'язання складних завдань діяльності;

- здатність до вияву ініціативи у прийнятті відповідальності;

- спроможність самостійно долати будь-які перешкоди у праці;

- збереження працездатності в екстремальних умовах на основі посилення самоконтролю психічних процесів, емоційних станів;

- здатність самостійно планувати власну діяльність на близьку та віддалену перспективи;

- усвідомлення особистої та суспільної значущості власної діяльності;

- здатність до самосуб'єктної дії за будь-яких умов: актуалізація внутрішніх потенційних можливостей, стійка потреба у самовдосконаленні своєї особистості у духовному та професійному планах;

- рівень спеціальних професійних знань.

Сформована одного разу самосуб'єктна активність не забезпечує кожний раз необхідних результатів навіть в аналогічних умовах діяльності. Тому для практичної діяльності необхідно знати, як здійснюється перехід від стійкої, тривалої до ситуативної самоактивності. При зустрічі з реальними труднощами професійної ситуації відбувається перебудова психічної діяльності фахівця, актуалізація раніш сформованих якостей. При цьому найчастіше увага звертається на зміни психологічної активності фахівця, на його налаштованість та змобілізованість на якісне виконання поставленого завдання. Саме явище «налаштованості» та «змобілізованості» тлумачиться неоднозначно, а іноді ці поняття використовуються як синоніми [2].

На нашу думку, викладачу корисно уявляти взаємозв’язок цих явищ та особливостей їх проходження на кожному рівні, тому подаємо власне тлумачення (табл. 1): На кожному рівні визначається специфічний перебіг психічної напруженості; яка має свої особливості адаптації, міжрівневої регуляції та саморегуляції, і тому свої можливості визначення показників та критеріїв готовності. 


\section{Наслідки прояву саморегулятивної активності курсанта}

\begin{tabular}{|c|c|c|c|}
\hline \multirow{2}{*}{$\begin{array}{l}\text { Зміни особистості } \\
\text { курсанта на рівні: }\end{array}$} & \multicolumn{2}{|c|}{$\begin{array}{c}\text { Наслідки у навчально-професійних ситуаціях та } \\
\text { їх прояви: }\end{array}$} & \multirow{2}{*}{$\begin{array}{l}\text { Методи вияву } \\
\text { саморегулятивної } \\
\text { активності }\end{array}$} \\
\hline & напруженість & адаптованість & \\
\hline \multirow[t]{2}{*}{$\begin{array}{l}\text { соціально- } \\
\text { психологічному }\end{array}$} & 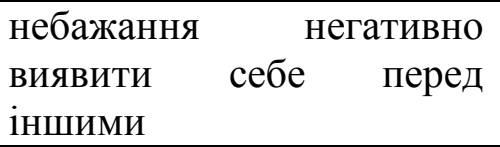 & $\begin{array}{l}\text { виконання дій на } \\
\text { очікуваному рівні }\end{array}$ & \multirow{2}{*}{$\begin{array}{l}\text { спостереження } \\
\text { аналіз } \\
\text { висловлювань } \\
\text { про власну } \\
\text { готовність }\end{array}$} \\
\hline & $\begin{array}{l}\text { очікування негативних } \\
\text { оціночних суджень } 3 \text { боку } \\
\text { керівника заняття та } \\
\text { iнших курсантів }\end{array}$ & $\begin{array}{l}\text { наслідування } \\
\text { досвіду кращих, } \\
\text { впливи, } \\
\text { налаштовують }\end{array}$ & \\
\hline \multirow{5}{*}{$\begin{array}{l}\text { індивідуально- } \\
\text { психологічному } \\
\text { (особистісному i } \\
\text { функціональному) }\end{array}$} & $\begin{array}{l}\text { сумніви у спроможності } \\
\text { подолати труднощі }\end{array}$ & $\begin{array}{l}\text { впевненість у собі } \\
\text { та інших }\end{array}$ & \multirow{5}{*}{$\begin{array}{l}\text { аналіз технології } \\
\text { виконання дій } \\
\text { аналіз ситуації } \\
\text { виникнення } \\
\text { потреби }\end{array}$} \\
\hline & $\begin{array}{llr}\text { підвищене } & \text { емоційне } \\
\text { реагування } & \text { на } & \text { впливи } \\
\text { труднощів } & & \end{array}$ & $\begin{array}{l}\text { позитивна } \\
\text { налаштованість на } \\
\text { подолання } \\
\text { труднощів; }\end{array}$ & \\
\hline & $\begin{array}{l}\text { зосередженість } \\
\text { власних переживаннях }\end{array}$ & безпомилкові дії & \\
\hline & страх зробити помилку; & \multirow{2}{*}{$\begin{array}{l}\text { зібраність, } \\
\text { зосередженість, } \\
\text { скоординоване } \\
\text { реагування } \\
\text { розпорядження }\end{array}$} & \\
\hline & $\begin{array}{l}\text { поява недоцільних рішень } \\
\text { і дій }\end{array}$ & & \\
\hline психофізіологічному & $\begin{array}{l}\text { відхилення } \\
\text { психофізіологічних } \\
\text { реакцій від норми }\end{array}$ & $\begin{array}{l}\text { стабілізація } \\
\text { рівні }\end{array}$ & $\begin{array}{l}\text { психофізіологічні } \\
\text { методи }\end{array}$ \\
\hline
\end{tabular}

Отже, саморегулятивна активність - явище багатопланове 3 проявами, в усіх підструктурах цілісної структури особистості.

Різні компоненти та прояви саморегулятивної активності до діяльності ще не мають необхідних доробки і систематизації. Але цілком очевидно, що в динамічній і цілісній структурі саморегулятивної активності $\epsilon$ певне стрижневе, спрямовуюче утворення. Це самосуб'єктні впливи (діi) забезпечення формування спроможності до яких стає важливим завданням підготовки курсантів.

Таким чином, забезпечення саморегулятивної активності у навчальнопрофесійній діяльності виступає кінцевою метою процесу підготовки курсанта. Проведене дослідження, типів, критеріїв, показників саморегулятивної активності у ситуаціях навчально-професійної діяльності та їх моделювання на рівні заняття має метою з'ясувати психолого-педагогічні умови ефективної підготовки курсантів до професійної діяльності в екстремальних умовах.

Оскільки елементи реальної предметно-практичної ситуації пов'язані між собою у прихований спосіб, не $є$ очевидними (середовищні, діяльнісні, особистісні), то зрозуміти завдання значить побудувати “зрозумілу" курсанту картину. Рішення завдання полягає у віднайдені причинно-наслідкових зв”язків, 
які, відповідно до поставленого завдання, були “невідомими”. Навчальнопрофесійне завдання виходить із змісту та специфіки професійної діяльності фахівців ДСНС Украйни і зводиться до проектування даних емпіричного типу, на відміну від знань теоретичних.

Для розв'язання навчально-професійних завдань курсант здійснює логічну рефлексію та усвідомлює способи організації власного мислення, необхідні для побудови та зміни груп мисленнєвих операцій. Застосування рефлексії передбачає його самозвіт і самоконтроль, оцінку себе та побудову концепцію себе-в-ситуації. Тільки в ході спроб вдосконалити форму свого мисленнєвого процесу та власну самоактивність під час виникнення відповідних ускладнень з'являється можливість здолати перешкоди. Розглянемо детальніше ці дії у вигляді певного циклу.

Завдання ставиться ззовні. В процесі його розуміння, прийняття та розв'язання воно по-різному усвідомлюється як предмет самоактивності курсанта. Спочатку стає зрозумілим зміст завдання та відбувається самовизначення суб'єкта. В результаті самовизначення започатковується ставлення до себе як того, хто може змінити власні потенціал на основі суб'єктних можливостей. Міра можливого напруження саморегулятивного впливу визначається у перебігу виконання завдань. Збільшення ступеню труднощів виконання завдання викликає зупинку процесів самоактивності.

Якщо індивідуальні особливості дають можливість курсанту впевнено впливати на регуляційні процеси, то їх проходження відбувається без ускладнень i напруження саморегулятивного впливу відповідає типу “звичайного”. Якщо умови здійснення саморегулятивного впливу приводять до відчуття неможливості пройти завдання без ускладнень, то ставлення і підхід курсанта до власної самоактивності є “напруженим", а ситуація “напруженою”.

Цикл складається із первинної спроби діяти або рішення діяти, ускладнень у діях, рефлексії або усвідомлення причини невдачі, зміни дій або їх регуляції, зміни себе у діях або саморегулятивних дій.

Ми розглядаємо його як вихідний пункт для характеристики двох типів навчально-професійної ситуації “звичайної” та “напруженоі”, а також, “звичайного" та "напруженого" характеру саморегулятивного впливу. Коли завдання розв'язується без проходження циклу, тоді воно не змінює суб'єкта і перестає мати розвивальне значення.

Моделювання навчально-професійної ситуації як “напруженої” передбачає, що курсант не може пройти цикл без ускладнень. Отже, цей тип ситуацій спрямований на прискорення змін суб'єкта через збільшення обсягу та значущості рефлексії, самовизначення, більших вимог до свідомості, самосвідомості, наполегливості особистості.

Він передбачає, що при виникненні ускладнень у проходженні циклу, курсант усвідомлює ситуацію ускладнення, виявляє його причину; завдяки цьому з'ясовує розбіжності між власним способом дій та обставинами, які виникають; виокремлює в обставинах те, що стосується способу досягнення 
мети; визначається щодо його прийнятності; відчуває суб'єктивну готовність до самозміни; реалізує новий спосіб дій та проявляє наполегливість у його реалізації.

Предметом перетворень у ситуації “із напруженням” (2-й тип) є спроможність курсанта та відповідні ій компетентності, а також його, суб'єктивне ставлення до дій, пов'язане із змінами власного “я”, а не лише досягненням мети. Тому, саморегулятивні впливи у ситуаціях такого типу спрямовані на вдосконалення механізму самозмін, тоді як у ситуаціях “без напруження" (1-й тип) саморегулятивні впливи спрямовані на використання вже наявних утворень, сформованих раніше, без можливості самозміни.

Якщо у розв'язанні завдань першого типу рівень рефлексивного самоаналізу визначається досягненням мети завдання, то у вирішенні завдань другого типу основним чинником успішності є чіткість уявлень про себе, свої потенції, здатність пролонгувати їх зміни, співвіднести власні спроможності та їх прояви, зокрема ті, що піддаються зовнішньому контролю.

Висновки. Проведене вивчення дозволяє сформулювати психологопедагогічні вимоги до організації психологічної підготовки курсантів на рівні окремого заняття та навчальної дисципліни, а також розкрити необхідні поняттєві засоби.. Керівник створює педагогічні ситуації з огляду на можливість самосуб'єктної регуляції для зміни та самозміни курсанта Створені ним умови передбачають, що курсант отримає практичний досвід самосуб'єктних впливів різних типів щодо рефлексії себе та фокусуванні контролю на досягненні мети, способах самосуб' єктного впливу, засобах самоорганізації.

Напрями подальших досліджень пов'язані із технологізацією всіх компонентів розвитку самоактивності курсанта та верифікацією елементів психолого-педагогічної технології. Завдяки яким, керівник заняття, водночас із формуванням певних компетентностей на тематичному матеріалі, формує у курсанта психологічні механізми самосуб'єктних впливів та самозміни; створює умови для функціонування у нього самосуб' єктної активності.

\section{ЛІТЕРАТУРА}

1. Боришевский М. Й. Развитие саморегуляции поведения школьников : автореф. дис. на здобуття наук. ступеня докт. псих. наук : спец. 19.00.07 "педагогічна та вікова психологія" / Боришевский Мирослав Йосипович - Інститут психології НАПН ім. Г.С. Костюка, 1992. - 77 c.

2. Грибенюк Г. С. Психологічні основи становлення саморегуляції у навчальнопрофесійній діяльності майбутніх рятівників : дис. докт. псих. наук : 19.00.07 - педа / Грибенюк Геннадій Сергійович - Інститут психології ім. Г.С. Костюка АПН Украї, 2007. $380 \mathrm{c.}$

3. Миронець С. М. Негативні психічні стани та реакції у працівників аварійнорятувальних підрозділів МНС України в умовах надзвичайної ситуації : автореф. дис. на здобуття наук. ступеня канд. психол. наук : спец. 19.00.09 «Психологія діяльності в особливих умовах» / С. М. Миронець. - Харків, 2007. - 21 С.

4. Приходько Ю. О. Психологічні чинники успішності професійної діяльності пожежних-рятувальників МНС України : дис. ... кандидата психологічних наук: 19.00.09 «Психологія діяльності в особливих умовах» / Приходько Юрій Олександрович. - К., 2008. $230 \mathrm{c}$. 
5. Снісаренко А. Г. Професіографічний аналіз діяльності начальників караулів Оперативно-рятувальної служби цивільного захисту МНС України : дис. ... кандидата психологічних наук: 19.00.09 - «Психологія діяльності в особливих умовах» / Снісаренко Андрій Григорович. - Х., 2011. - 243 с.

6. Постанова Кабінету Міністрів України від 23.11.2011 р. № 1341 «ро затвердження Національної рамки кваліфікацій» [Електронний ресурс] // Урядовий кур'єр від 18.01.2012 № 9,. - 2012. - Режим доступу до ресурсу: http://zakon2.rada.gov.ua/laws/show/1341-2011$\% \mathrm{D} 0 \% \mathrm{BF}$

7. Корольчук М.С. Теорія і практика професійного психологічного відбору : навч. посіб. / М.С. Корольчук, В.М. Крайнюк. - К. : Ніка-Центр, 2006. - 532 с.

8. Макаренко М.В. Основи професійного відбору військових спеціалістів та методики вивчення індивідуальних психофізіологічних відмінностей між людьми / М.В. Макаренко. К. : Ін-т фізіології ім. О.О. Богомольця НАН України, Науково-дослідний центр гуманітарних проблем ЗС України, 2006. - 395 с.

9. Малхазов О.Р. Впровадження спеціальних психофізіологічних технологій у систему профвідбору фахівців для авіаційної галузі України / О.Р. Малхазов, В.П. Бабак, В.П. Харченко // Наука та інновації. - 2007. - Т. 3, № 5. - С. 36-52.

10. Макаренко М.В. Основи професійного відбору військових спеціалістів та методики вивчення індивідуальних психофізіологічних відмінностей між людьми / М.В. Макаренко. К. : Ін-т фізіології ім. О.О. Богомольця НАН України, Науково-дослідний центр гуманітарних проблем ЗС України, 2006. - 395 с.

\section{REFERENCES}

1. Boryshevskyi M. Y. Razvytye samorehuliatsyy povedenyia shkolnykov : avtoref. dys. na zdobuttia nauk. stupenia dokt. psykh. nauk : spets. 19.00.07 "pedahohichna ta vikova psykholohiia" / Boryshevskyi Myroslav Yosypovych - Instytut psykholohii NAPN im. H.S. Kostiuka, 1992. $77 \mathrm{~s}$.

2. Hrybeniuk H. S. Psykholohichni osnovy stanovlennia samorehuliatsii u navchalnoprofesiinii diialnosti maibutnikh riativnykiv : dys. dokt. psykh. nauk : 19.00 .07 - peda / Hrybeniuk Hennadii Serhiiovych - Instytut psykholohii im. H.S. Kostiuka APN Ukrai, 2007. - $380 \mathrm{~s}$.

3. Myronets S. M. Nehatyvni psykhichni stany ta reaktsii u pratsivnykiv avariino-riatuvalnykh pidrozdiliv MNS Ukrainy $\mathrm{v}$ umovakh nadzvychainoi sytuatsii : avtoref. dys. na zdobuttia nauk. stupenia kand. psykhol. nauk : spets. 19.00.09 «Psykholohiia diialnosti v osoblyvykh umovakh»/S. M. Myronets. - Kharkiv, 2007. - 21 S.

4. Prykhodko Yu. O. Psykholohichni chynnyky uspishnosti profesiinoi diialnosti pozhezhnykh-riatuvalnykiv MNS Ukrainy : dys. ... kandydata psykholohichnykh nauk: 19.00.09 «Psykholohiia diialnosti v osoblyvykh umovakh» / Prykhodko Yurii Oleksandrovych. - K., 2008. $230 \mathrm{~s}$.

5. Snisarenko A. H. Profesiohrafichnyi analiz diialnosti nachalnykiv karauliv Operatyvnoriatuvalnoi sluzhby tsyvilnoho zakhystu MNS Ukrainy : dys. ... kandydata psykholohichnykh nauk: 19.00.09 - «Psykholohiia diialnosti v osoblyvykh umovakh»/ Snisarenko Andrii Hryhorovych. Kh., 2011. $-243 \mathrm{~s}$.

6. Postanova Kabinetu Ministriv Ukrainy vid 23.11.2011 r. № 1341 «Pro zatverdzhennia Natsionalnoi ramky kvalifikatsii» [Elektronnyi resurs] // Uriadovyi kurier vid 18.01.2012 № 9,. 2012. - Rezhym dostupu do resursu: http://zakon2.rada.gov.ua/laws/show/1341-2011-\%D0\%BF

7. Korolchuk M.S. Teoriia i praktyka profesiinoho psykholohichnoho vidboru : navch. posib. / M.S. Korolchuk, V.M. Krainiuk. - K. : Nika-Tsentr, 2006. - 532 s.

8. Makarenko M.V. Osnovy profesiinoho vidboru viiskovykh spetsialistiv ta metodyky vyvchennia indyvidualnykh psykhofiziolohichnykh vidminnostei mizh liudmy / M.V. Makarenko. K. : In-t fiziolohii im. O.O. Bohomoltsia NAN Ukrainy, Naukovo-doslidnyi tsentr humanitarnykh problem ZS Ukrainy, 2006. - 395 s. 
9. Malkhazov O.R. Vprovadzhennia spetsialnykh psykhofiziolohichnykh tekhnolohii u systemu profvidboru fakhivtsiv dlia aviatsiinoi haluzi Ukrainy / O.R. Malkhazov, V.P. Babak, V.P. Kharchenko // Nauka ta innovatsii. - 2007. - T. 3, № 5. - S. 36-52.

10. Makarenko M.V. Osnovy profesiinoho vidboru viiskovykh spetsialistiv ta metodyky vyvchennia indyvidualnykh psykhofiziolohichnykh vidminnostei mizh liudmy / M.V. Makarenko. K. : In-t fiziolohii im. O.O. Bohomoltsia NAN Ukrainy, Naukovo-doslidnyi tsentr humanitarnykh problem ZS Ukrainy, 2006. - 395 s.

\section{РЕЗЮМЕ \\ Геннадій Грибенюк, доктор психологічних наук, профессор, Черкасский институт пожарной безопасности имени Героев Чернобыля НУГЗ Украины, г. Черкассы}

\section{Развитие характеристик самоактитвности курсанта}

Резюме. В статье раскрываются особенности проведенного анализа действий преподавателя по развитию самоактивности курсантов на занятии. Представленные результаты работы позволяют определить, исходя из специфики профессиональной деятельности Государственной службы по чрезвычайным ситуачиям Украины, необходимые обоснованные критерии и виды самосубъектной активности курсантов. Дальнейшие исследования необходимы для изучении психологических условий эффективной подготовки курсантов в высших учебных заведениях.

Ключевые слова: самоактивность; курсант; самосубъектная активность; саморегулячія; самосубьектное действие.

\section{SUMMARY}

Hennadyi Hrybeniuk, D.Sc. in psychology, professor, Cherkasy Institute of Fire Safety named after Chornobyl Heroes of National University of Civil Defence of Ukraine, c. Cherkasy

\section{Development of characteristics self-activitty of the cadet}

Resume.The article reveals the features of the analysis of actions of the teacher of development of self-activity of cadets on occupation is carried out. The presented results of the work allow define based on the specifics of professional activity of the State emergenciy service of Ukraine necessary of reasonable criteria and types of self-subject activity of cadets. Further research is needed to explore the psychological conditions for effective training of cadets in higher.

Key words: self-activity; cadet; self-subject activity; autoregulation; autosubject actior; extreme mind. 